\title{
Vršnjačko nasilje u osnovnim školama Bjelovarsko-bilogorske županije
}

Bullying in elementary schools at Bjelovarsko-bilogorska County

\author{
Zrinka Puharić, Marija Baričević \\ Visoka tehnička škola u Bjelovaru, Stručni studij sestrinstva, Trg Eugena Kvaternika 4, 43000 Bjelovar, Hrvatska \\ Technical High School in Bjelovar, Professional Degree in Nursing, Trg Eugena Kvaternika 4, 43000 Bjelovar, Croatia
}

\section{Sažetak:}

Cilj: Cilj je ovoga rada bio ispitati prevalenciju vršnjačkog nasilja u školi, mogućnosti intervencije i ulogu škole u mišljenjima i stavovima nastavnika i stručnih suradnika šest osnovnih škola Bjelovarsko-bilogorske županije.

Ispitanici i metode: Ispitivanje je provedeno tijekom travnja, svibnja i lipnja 2013. godine. Uključeno je 100 nastavnika, profesora i stručnih suradnika šest osnovnih škola Bjelovarsko-bilogorske županije. Anketa je bila anonimna, uz prethodnu dozvolu ravnatelja. Korištena je anketa vodećeg svjetskog stručnjaka za nasilje među vršnjacima, Dana Olweusa. Statistička obrada podataka obavljena je s pomoću MS Excela i korišten je x2-test za utvrđivanje postojanja razlika s obzirom na spol i godine radnoga staža ispitanika.

Rezultati: Na osnovi dobivenih rezultata možemo zaključiti da je nasilje među vršnjacima u školama Bjelovarsko-bilogorske županije postao "trend“. Nastavnici vjeruju da učenici koji su zlostavljani podjednako razgovaraju o toj temi s roditeljima, ostalim nastavnicima i/ili prijateljima. Nastavnici nasilje među vršnjacima najviše viđaju u svojim učionicama, nisu ravnodušni prema njemu, vjeruju da škola ima iznimno jasna pravila o nasilničkom ponašanju među učenicima. Također, u velikom postotku nastavnici vjeruju da su ona iznimno jasno priopćena nastavnom osoblju i prilično jasno priopćena roditeljima.

Zaključak: Osim što nasilje predstavlja problem u školama, ono predstavlja problem i u društvu. Trebalo bi raditi na podizanju javne svijesti o vršnjačkom nasilju i posljedicama vršnjačkog nasilja u različitim oblicima javnih kampanja, te poslati jasnu poruku javnosti da ne toleriramo nasilje u našim školama i među našom djecom.

Ključne riječi: nasilje • žrtve • nasilnici • škola • prevalencija • prevencija nasilja Kratki naslov: Nasilje i škole

\begin{abstract}
:
Aims: The objective of this study was to examine the prevalence of bullying in schools, possibilities of intervention and the role of schools through the opinions and attitudes of teachers and other stuff at six elementary schools in Bjelovarsko-bilogorska County.
\end{abstract}

Subjects and Methods: The study was conducted during April, May and June 2013. year. The study included 100 teachers, professors and stuff of 6 elementary schools Bjelovarsko-bilogorska County. The survey was organized anonymously, with prior permission of the principal. Survey that was used is oneof the world's leading experts on violence among peers, Dan Olweus. Statistical analysis was performed using MS Excel and used test for determining the existence of differences with regard to gender and years of service of respondents.

Results: Based on the obtained results, we can conclude that peer violence in schools Bjelovarsko-bilogorska County become a trend. believe that students who have problems talk about it with their parents, other teachers and/or friends. Teachers see most of the violence among peers in their classrooms, they are not indifferent to it, they believe that the school has a very clear rules on bullying among students. Also, a large percentage of teachers believe they have the same very clearly rules about bullying and parents know about that.

Conclusion: Bullying is a problem at schools and it is a problem in society. It takes work to increase public awareness of the consequences of peer violence and bullying through various forms of public campaigns, and send a clear message to the public that violence in our schools and among our children will not be tolerated.

Keywords: bullying $\bullet$ victims $\bullet$ bullies $\bullet$ school $\bullet$ prevalence $\cdot$ violence prevention Running head: Violence and schools

Autor za korespondenciju/Corresponding author: Zrinka Puharić, PhD., Technical High School in Bjelovar, Professional Degree in Nursing, Trg Eugena Kvaternika 4, 43000 Bjelovar, Croatia • Tel: +385-043 241201·Fax:+385-043 241202·Mob:+385-91 7981653•E-mail:zpuharic@vtsbj.hr

\section{Uvod / Introduction}

Posljednjih desetljeća svjedoci smo slučajeva ekstremnog vršnjačkog nasilja. Kako raste broj zlostavljača, tako raste i interes javnosti za probleme zlostavljane djece. Zlostavljanje se javlja u različitim razdobljima i kulturama, pa tako i u hrvatskim školama sve češće tome svjedočimo. Budući da djeca najviše vremena provode u školi i u sklopu škole, logično je da je zlostavljanje ondje prilično često.

Većina se ljudi tijekom odrastanja susretne s nekim oblikom nasilja među vršnjacima. Prije se vjerovalo da je to sastavni dio odrastanja i kako takvo iskustvo može pomoći djeci da ojačaju. No, danas je dokazano kako iskustvo nasilja među vršnjacima, pogotovo ako mu je dijete izloženo tijekom dužeg perioda, ima štetne posljedice za djetetov fizički i psihički razvoj te njegovo obrazovanje. Tek je 1970-ih godina počeo veći interes istraživača za ovo područje, a prva istraživanja pokrenuta su u skandinavskim zemljama [1].

Prvu definiciju nasilja među vršnjacima dao je Olweus (1998.) koji navodi da je učenik zlostavljan ili viktimiziran 
kada su ona ili on opetovano i trajno izloženi negativnim postupcima jednoga učenika ili više njih [2].

Zlostavljanje počinje još u predškolskoj dobi, s prelaskom u više razrede sve je izraženije, a njegova učestalost opada tijekom srednje škole. Povedeni tom činjenicom, moramo priznati da je najbitnije učenicima osigurati sigurno ozračje, gdje će se osjećati zaštićeno i prihvaćeno, bez izloženosti zadirkivanju, uznemiravanju, zastrašivanju, nazivanju pogrdnim imenima i nasilju. Tu na red dolaze nastavnici, profesori i stručni suradnici, koji su mnogo puta bili svjedocima nasilja među vršnjacima ili su čuli glasine o tome.

Važno je uvidjeti da danas mislimo kako je nasilništvo potpuno neprihvatljivo. Ono se smatra zlostavljanjem i nije mu mjesto u našim školama. Škole bi trebale poduzimati učinkovite mjere kako bi spriječile nasilništvo u školama. Međutim, istraživanja su pokazala da se nasilništvo, premda ga je moguće znatno smanjiti, ne može potpuno iskorijeniti iz škola.

Kod drugog navedenog pristupa klasifikacije nasilnog ponašanja potrebno je spomenuti Olweusa (1998.), koji razlikuje dvije vrste nasilništva: izravna i neizravna nasilnička ponašanja. U izravne oblike nasilja ubrajaju se svi izravni i otvoreni napadi na žrtvu, bilo verbalni ili fizički, poput izrugivanja, psovanja i vrijeđanja, ili pak guranja, šamaranja, udaranja i sl. Neizravni oblici nasilja među djecom suptilniji su i teže ih je uočiti, a uključuju ignoriranje, isključivanje iz društva i sl. [3].

Nasilništvo se može kretati u rasponu od šala do nasilnih kaznenih djela. Ono uključuje:

šale

bolno zadirkivanje,

neugodan govor tijela

guranje i naguravanje

zlobno ogovaranje

rasističke primjedbe

isključivanje

iznuđivanje

zloporabu telefona i interneta

spolno uznemiravanje

oštećivanje stvari

tjelesno nasilje

uporabu oružja

kaznena djela...

Vršnjačko nasilje definira se kao izloženost namjerno negativnom, ponavljanom djelovanju jednog ili više učenika, nerazmjerne stvarne ili percipirane snage, zbog koje dijete trpi tjelesnu i/ili emocionalnu štetu, a nemoćno je da se odupre.

U okviru definicije ističu se tri bitna elementa: trajanje, negativni postupci i neravnopravan odnos snaga. Stoga moramo razlikovati nasilje među vršnjacima od uobičajenog sukoba. Postoji nekoliko ključnih elemenata koji su u osnovi nasilja među vršnjacima:

- namjera da se povrijedi, ozlijedi ili nanese fizička, socijalna ili emocionalna šteta,

- žrtva ga nije isprovocirala
- neravnopravnost moći, odnosno, snage u odnosu između žrtve i počinitelja nasilja. Stvarni i/ili percipirani nerazmjer snaga može se pojaviti u situacijama ako je učenik (žrtva) zaista fizički slabiji od učenika (počinitelja nasilja), ako žrtva sebe doživljava fizički ili mentalno slabijom te ako postoji brojčani nerazmjer između žrtve i zlostavljača,

- događa se bar jednom na tjedan, odnosno, postoji prijetnja daljnjim nasiljem,

- kada nasilje eskalira, u djece žrtava pojavljuje se strah, koji omogućava počinitelju nasilja da nastavi zlostavljanje vjerujući da neće biti prijavljen.

Koliko je nasilje među vršnjacima raširena pojava, najbolje prikazuju rezultati opsežne studije Svjetske zdravstvene organizacije koja je provedena u 40 država svijeta 2005. i 2006. godine. Istraživanje raširenosti nasilja među djecom i mladima Svjetske zdravstvene organizacije dio je šire studije o zdravlju i ponašanju djece školske dobi. U istraživanju je sudjelovalo 202056 djece i mladih (od 11, 13 i 15 godina). Rezultati pokazuju kako je nasilje među djecom i mladima raširena pojava koju prijavljuje $10,7 \%(\mathrm{~N}=21,192)$ djece i mladih. Zanimljivo je da u baltičkim zemljama poput Latvije, Estonije i Litve, djeca i mladi prijavljuju najvišu stopu nasilnog ponašanja, dok je u skandinavskim zemljama, poput Norveške, Švedske i Finske, zabilježena najniža stopa.

U spomenutom istraživanju Svjetske zdravstvene organizacije od ukupnog broja sudionika istraživanja, njih 10,7\% možemo svrstati u skupinu nasilnika, 12,6\% djece nalazi se u ulozi žrtve te izjavljuje kako svakodnevno doživljava nasilnička ponašanja od svojih vršnjaka. Zanimljivo je da su dječaci u višoj stopi osobe koje čine nasilje u svim zemljama koje su sudjelovale $u$ istraživanju, dok su stope doživljenog nasilja više kod djevojčica u čak 29 od ukupno 40 zemalja [4].

Za Hrvatsku ćemo navesti dva bitna istraživanja. Prvo je ono HBSC-a koje je u istraživanje uključilo i pitanja vezana uz nasilje među učenicima pod nazivom „Ponašanje u vezi sa zdravljem u djece školske dobi - 2009/2010." Na pitanje „Koliko su te često u školi zlostavljali zadnjih nekoliko mjeseci?", $82 \%$ dječaka i $84 \%$ djevojčica izjavilo je da ih nikada vršnjaci nisu zlostavljali, 11\% dječaka i 10\% djevojčica bilo je zlostavljano jedanput ili dvaput u posljednjih nekoliko mjeseci, $2 \%$ dječaka i $2 \%$ djevojčica bilo je zlostavljano dva ili tri puta mjesečno, $2 \%$ dječaka i $2 \%$ djevojčica bilo je zlostavljano otprilike jednom tjedno, a $4 \%$ dječaka i 3\% djevojčica bilo je zlostavljano više puta tjedno. Prema tome, svaki šesti dječak i svaka šesta djevojčica smatraju da su u posljednjih nekoliko mjeseci bili izloženi nasilju svojih vršnjaka. No, svaki četvrti dječak i svaka sedma djevojčica bili su nasilni prema svojim vršnjacima u školi. Nasilništvo prema drugima doseže vrhunac u sedmom razredu, kada je i pubertetsko razdoblje najburnije. Prema trenutno raspoloživim međunarodnim podacima, Republika Hrvatska je,s obzirom na udio žrtava nasilja među vršnjacima, a u donjoj trećini ljestvice prema udjelu djece koja zlostavljaju svoje vršnjake [5].

Poliklinika za zaštitu djece grada Zagreba provela je 2003. godine istraživanje o vršnjačkom nasilju među djecom u 
školi (bullying). Istraživanje je obuhvaćalo 25 osnovnih škola u 13 gradova Republike Hrvatske, a sudionici ispitivanja učenici su od 4. do 8. razreda. Prema njihovim rezultatima, 27\% djece svakodnevno doživljava neke oblike nasilja u školi (verbalnog i tjelesnog). 16\% djece gotovo se svakodnevno ponaša nasilno prema drugoj djeci, pri čemu $8 \%$ djece istodobno i čini i doživljava nasilje. Dječaci se znatno češće ponašaju nasilno, ali i doživljavaju nasilje. Od desete do četrnaeste godine povećava se učestalost nasilnog ponašanja, osobito verbalnog, što znatno pogoršava školski uspjeh djece.žrtava, ali i djece koja su nasilnici. Zabrinjavajuće je da se samo $22 \%$ djece žrtava nasilja obrati odrasloj osobi za pomoć, od toga $11 \%$ obratilo se za pomoć nastavnicima [6].

Upravo zbog svega navedenog i ekstremnog porasta nasilja među vršnjacima, cilj ovoga rada bilo je ispitati stručne osobe koje rade $s$ djecom u kojoj mjeri provode intervencije za sprječavanje nasilja među vršnjacima, te upozoriti na važnost prevencije nasilja kako bi učionica bila sigurno mjesto gdje svi učenici mogu slobodno i bez straha učiti.

\section{Ispitanici i metode / Subjects and Methods}

Ispitivanje je provedeno tijekom travnja, svibnja i lipnja 2013. godine u šest osnovnih škola Bjelovarsko-bilogorske županije. Ukupno je u tim školama zaposleno 208 nastavnika i stručnih suradnika, od toga 160 ženskih i 48 muških, a odlučilo je sudjelovati u anketiranju ukupno 100 nastavnika i stručnih suradnika, od toga 81 ženskih i 19 muških. U odnosu na mogući broj ispitanika (muških i ženskih), podjednak odaziv je bio u oba spola, što nam potvrđuje $\chi 2$-test, uz stupanj slobode 1 (df) i nivo značajnosti $95 \%$. [ $\chi 2$ test $=0.44$; $\mathrm{p}<0,507] \mathrm{U}$ iostraživanje je uključeno 100 nastavnika, profesora i stručnih suradnika osnovnih škola.

Anketiranje je organizirano anonimno, uz prethodnu dozvolu ravnatelja.

Nastavnici su dobili upute za rješavanje ankete uz kratak podsjetnik što smatramo neprihvatljivim i nasilnim ponašanjem. Ispitivanje je provedeno na sjednicama učiteljskoga vijeća.

Statistička obrada podataka obavljena je s pomoću MS Excela i korišten je X2-test za utvrđivanje postojanja razlika s obzirom na spol i godine radnoga staža ispitanika.

\section{Rezultati / Results}

\section{Pitanje [1] Koliko često učenici kažu da su zlostavljani?}

$26.7 \%$ ispitanika misli da učenici često razgovaraju o nasilju, dok njih samo $4 \%$ misli da gotovo nikada ne razgovaraju o nasilju.

Pitanje [2] Koliko ste često uočili nasilničko ponašanje među učenicima u Vašoj učionici, u školskoj kuhinji ili kafiću?

Nastavnici češće viđaju nasilje u svojim učionicama nego drugdje u školi (čak 45,0\%)

Pitanje [3] Koliko često vjerujete da su učenici bili zlostavljani na školskim hodnicima ili idući u školu i vraćajući se iz nje?
Nastavnici vjeruju da se nasilje odvija jednakim intenzitetom i u školi i izvan nje (45\%: 46\%)

Pitanje [4] Od početka ovoga polugodišta, koliko su Vas često učenici izvijestili da su bili zlostavljani ili da su ih drugi učenici zlostavljali?

Čak 30 \% nastavnika nije nikada s učenicima razgovaralo o toj problematici.

Pitanje [5] Ako ste uočili nasilničko ponašanje među učenicima, ili ako su Vas učenici izvijestili o njemu, koliko ste često intervenirali razgovorom u ovome polugodištu?

Nastavnici često (u prosjeku, 29\%) razgovaraju sa školskom stručnom službom (pedagog, psiholog, defektolog) ili s drugim nastavnicima o nasilju među učenicima, ali s druge strane rijetko razgovaraju s ravnateljem škole. 17,5\% nastavnika nikada nije interveniralo razgovorom iako su svjesni da su oni odgovorni za svoje učenike.

Pitanje [6] Ako ste uočili nasilničko ponašanje među učenicima ili ako su Vas učenici izvijestili o njemu, koliko ste često prijavili ovaj incident roditeljima ovo polugodište?

$36 \%$ nastavnika uvijek obavijesti roditelje o nasilju u njihovoj učionici, međutim, nije zanemariv postotak od $27 \%$ nastavnika koji nikada ne obavijeste roditelje o nasilju u učionici.

Pitanje [7] Od početka ovoga polugodišta, koliko ste često razgovarali s roditeljima djece koja su zlostavljala druge (tj. govorili o djetetovu nasilju)?

Čak 34\% nastavnika nikada ne razgovara s roditeljima, a njih 36\% razgovaralo je samo jedanput ili dvaput od početka ovoga polugodišta.

Pitanje [8] Od početka ovoga polugodišta, koliko ste često razgovarali s pojedinim učenicima, u svojoj školi, o nasilničkom ponašanju prema drugima?

Samo 4\% nastavnika nikada ne razgovara s učenicima o nasilničkom ponašanju prema drugima učenicima.

Pitanje [9] Od početka ovoga polugodišta, koliko ste često razgovarali s pojedinim učenicima o nasilničkom ponašanju nad njima?

Nastavnici manje razgovaraju sa žrtvama nasilja od samih nasilnika. Čak 20\% nastavnika nikada ne razgovara s učenicima o nasilničkom ponašanju nad njima.

Pitanje [10] Je li Vam jasno što trebate učiniti kako biste odgovorili na nasilje koje ste promatrali ili ste čuli o njemu u svojoj školi?

49\% nastavnika prilično jasno zna što treba učiniti kako bi odgovorili na nasilje, a njima $44 \%$ to je iznimno jasno. Malen, ali ne i zanemariv, jest postotak od $6 \%$ kojima je prilično nejasno, a samo $1 \%$ iznimno nejasno.

Pitanje [11] Vjerujete li da Vaša škola ima jasna pravila ili politiku o nasilničkom ponašanju među učenicima?

Školska pravila ili politika o nasilničkom ponašanju među učenicima prilično je jasna $46 \%$ nastavnika i iznimno jasna $40 \%$ nastavnika, što je pohvalan podatak. Zabrinjava nas $14 \%$ nastavnika kojima su pravila prilično nejasna.

Pitanje [12] Vjerujete li da su Vaša školska pravila ili politika o nasilničkom ponašanju jasno priopćena roditeljima i nastavnom osoblju? 
Nastavnici u velikom postotku vjeruju da su školska pravila ili politika o nasilničkom ponašanju jasno priopćena i roditeljima i nastavnom osoblju.

Pitanje [13] Koliko su Vam ugodne intervencije na nasilničko ponašanje koje promatrate u svojoj školi?

Da su intervencije na nasilničko ponašanje prilično neugodne, izjavljuje čak 50\% nastavnika. Njih 30\% kaže da su zasigurno neugodne, a ugodne su njima $10 \%$, od toga prilično ugodne $7 \%$ i iznimno ugodne $3 \%$.
Pitanje [14] Koliki je postotak učenika u Vašoj školi za koje vjerujete da su zlostavljali druge učenike jedanput na tjedan ili više, od početka ovoga polugodišta?

$84 \%$ nastavnika vjeruje da u njihovoj školi postoji 0-25\% učenika koji zlostavljaju druge učenike jedanput na tjedan ili više, čak $15 \%$ nastavnika vjeruje da je tih učenika 25-50\%, a $1 \%$ nastavnika vjeruje da je $50-75 \%$ učenika zlostavljača.

Nakon toga testirali smo razliku u odgovorima na sva pitanja s obzirom na spol zaposlenika.

TABLıCA [1] Statistička značajnost stavova i mišljenja nastavnika i stručnih suradnika s obzirom na spol.

\begin{tabular}{|c|c|c|c|}
\hline Anketna pitanja & $X^{2}$ - test & df & $\mathbf{p}$ \\
\hline Što mislite, koliko često učenici kažu nastavniku kada su bili zlostavljani? & 7,55 & 4 & 0,1095 \\
\hline Što mislite, koliko često učenici kažu roditeljima kada su bili zlostavljani? & 8,99 & 4 & 0,0613 \\
\hline Što mislite, koliko često učenici kažu prijateljima kada su bili zlostavljani? & 7,63 & 4 & 0,1061 \\
\hline Navedite koliko ste često uočili nasilničko ponašanje među učenicima u Vašoj učionici. & 1,99 & 4 & 0,7376 \\
\hline Navedite koliko ste često uočili nasilničko ponašanje među učenicima u školskoj kuhinji ili u kafiću. & 4,81 & 4 & 0,3074 \\
\hline Navedite koliko često vjerujete da su učenici bili zlostavljani na školskim hodnicima. & 1,64 & 4 & 0,8016 \\
\hline Navedite koliko često vjerujete da su učenici bili zlostavljani idući u školu i vraćajući se iz nje. & 1,85 & 4 & 0,7633 \\
\hline $\begin{array}{l}\text { Od početka ove školske godine, koliko ste često primijetili da učenik laže ili širi neistinite glasine kako } \\
\text { drugi učenici ne bi voljeli drugoga učenika? }\end{array}$ & 2,67 & 4 & 0,6145 \\
\hline $\begin{array}{l}\text { Od početka ovoga polugodišta, koliko su Vas često učenici izvijestili da su bili zlostavljani (iako } \\
\text { možda nisu koristili izraz nasilje)? }\end{array}$ & 1,07 & 4 & 0,899 \\
\hline $\begin{array}{l}\text { Od početka ovoga polugodišta, koliko su Vas često učenici izvijestili da su drugi učenici zlostavljani } \\
\text { (iako možda nisu koristili izraz nasilje)? }\end{array}$ & 6,69 & 4 & 0,1532 \\
\hline $\begin{array}{l}\text { Ako ste uočili nasilničko ponašanje među učenicima ili ako su Vas učenici izvijestili o njemu, koliko } \\
\text { ste često prijavili ovaj incident roditeljima ovo polugodište? }\end{array}$ & 0,84 & 4 & 0,933 \\
\hline $\begin{array}{l}\text { Ako ste uočili nasilničko ponašanje među učenicima ili ako su Vas učenici izvijestili o njemu, koliko } \\
\text { ste često ovo polugodište razgovarali o incidentu s ravnateljem? }\end{array}$ & 2,81 & 4 & 0,5901 \\
\hline $\begin{array}{l}\text { Ako ste uočili nasilničko ponašanje među učenicima ili ako su Vas učenici izvijestili o njemu, koliko } \\
\text { ste često ovo polugodište razgovarali o incidentu sa stručnom službom škole (pedagog, psiholog, } \\
\text { defektolog)? }\end{array}$ & 2,51 & 4 & 0,6428 \\
\hline $\begin{array}{l}\text { Ako ste uočili nasilničko ponašanje među učenicima ili ako su Vas učenici izvijestili o njemu, koliko } \\
\text { ste često ovo polugodište razgovarali o incidentu s drugim nastavnikom? }\end{array}$ & 1,28 & 4 & 0,8648 \\
\hline $\begin{array}{l}\text { Ako ste uočili nasilničko ponašanje među učenicima ili ako su Vas učenici izvijestili o njemu, koliko } \\
\text { ste često razgovarali ovo polugodište o incidentu s drugim djelatnikom u školi? }\end{array}$ & 1,05 & 4 & 0,9021 \\
\hline $\begin{array}{l}\text { Od početka ovoga polugodišta, koliko ste često razgovarali s pojedinim učenicima, u svojoj školi, o } \\
\text { nasilničkom ponašanju prema drugima? }\end{array}$ & 4,32 & 4 & 0,3644 \\
\hline $\begin{array}{l}\text { Od početka ovoga polugodišta, koliko ste često razgovarali s roditeljima djece koja su zlostavljala } \\
\text { druge (tj. govorila o djetetovu nasilju)? }\end{array}$ & 2,38 & 4 & 0,6662 \\
\hline $\begin{array}{l}\text { Od početka ovoga polugodišta, koliko ste često razgovarali s pojedinim učenicima o nasilničkom } \\
\text { ponašanju nad njima? }\end{array}$ & 3,9 & 4 & 0,4197 \\
\hline Od početka školske godine, koliko ste često razgovarali sa svojom obitelji o nasilju? & 1,24 & 4 & 0,8715 \\
\hline Vjerujete li da Vaša škola ima jasna pravila ili politiku o nasilničkom ponašanju među učenicima? & 4,94 & 3 & 0,1762 \\
\hline Vjerujete li da su Vaša školska pravila i politika o nasilničkom ponašanju jasno priopćena roditeljima? & 1,23 & 3 & 0,7458 \\
\hline $\begin{array}{l}\text { Vjerujete li da su Vaša školska pravila i politika o nasilničkom ponašanju jasno priopćena nastavnom } \\
\text { osoblju? }\end{array}$ & 2,18 & 3 & 0,5359 \\
\hline $\begin{array}{l}\text { Je li Vam jasno što trebate učiniti kako biste odgovorili na nasilje koje ste promatrali ili ste čuli o } \\
\text { njemu u svojoj školi? }\end{array}$ & 5,74 & 3 & 0,125 \\
\hline Koliko su Vam ugodne intervencije na nasilničko ponašanje koje promatrate u svojoj školi? & 2,1 & 3 & 0,5519 \\
\hline $\begin{array}{l}\text { Koliki je postotak učenika u Vašoj školi za koje vjerujete da su zlostavljali druge učenike jedanput na } \\
\text { tjedan ili više, od početka ovoga polugodišta? }\end{array}$ & 2,04 & 3 & 0,5641 \\
\hline
\end{tabular}


Iz rezultata vidimo da nema statistički znatne razlike $s$ obzirom na spol anketiranih nastavnika, dakle, i muški i ženski nastavnici jednako se odnose prema problemu vršnjačkog nasilja.

Nakon toga testirali smo razliku u odgovorima na sva pitanja s obzirom na duljinu radnog staža zaposlenika, gdje smo zaposlenike podijelili u četiri skupine: 1 . do 10 godina radnog staža, 2. 10-20 godina radnog staža, 3. 20-30 godina radnog staža i 4 . više od 30 godina radnog staža. $\chi 2$-test pokazao je da statistički značajna razlika postoji samo u dva pitanja od ukupno dvadeset i pet. Odnosno, nastavnici i stručni suradnici s obzirom na godine radnoga staža razilaze u mišljenju kada je pitanje koliko često učenici kažu roditeljima kada su bili zlostavljani $\chi 2(12)=21,84$, $\mathrm{p}<0,0394$, te koliko često učenici kažu prijateljima kada su bili zlostavljani, $\chi 2(12)=35,16, p<0,0004$. Iz toga možemo zaključiti da nastavnici s više godina radnoga staža manje vjeruju u to da se žrtve zlostavljanja povjeravaju svojim roditeljima i prijateljima.

TABLıCA [2] Statistička značajnost stavova i mišljenja nastavnika i stručnih suradnika s obzirom na godine radnoga staža

\begin{tabular}{|c|c|c|c|}
\hline Anketna pitanja & $x^{2}$ - test & df & $\mathbf{p}$ \\
\hline Što mislite, koliko često učenici kažu nastavniku kada su bili zlostavljani? & 17,75 & 12 & 0,1235 \\
\hline Što mislite, koliko često učenici kažu roditeljima kada su bili zlostavljani? & 21,84 & 12 & 0,0394 \\
\hline Što mislite, koliko često učenici kažu prijateljima kada su bili zlostavljani? & 35,16 & 12 & 0,0004 \\
\hline Navedite koliko ste često uočili nasilničko ponašanje među učenicima u Vašoj učionici. & 20,16 & 12 & 0,0641 \\
\hline Navedite koliko ste često uočili nasilničko ponašanje među učenicima u školskoj kuhinji ili u kafiću. & 14,46 & 12 & 0,2723 \\
\hline Navedite koliko često vjerujete da su učenici bili zlostavljani na školskim hodnicima. & 14,88 & 12 & 0,2481 \\
\hline Navedite koliko često vjerujete da su učenici bili zlostavljani idući u školu i vraćajući se iz nje? & 9,01 & 12 & 0,7021 \\
\hline $\begin{array}{l}\text { Od početka ove školske godine, koliko ste često primijetili da učenik laže ili širi neistinite glasine kako } \\
\text { drugi učenici ne bi voljeli drugoga učenika? }\end{array}$ & 7,84 & 12 & 0,7975 \\
\hline $\begin{array}{l}\text { Od početka ovoga polugodišta, koliko su Vas često učenici izvijestili da su bili zlostavljani (iako } \\
\text { možda nisu koristili izraz nasilje)? }\end{array}$ & 7,37 & 12 & 0,8322 \\
\hline $\begin{array}{l}\text { Od početka ovoga polugodišta, koliko često su Vas učenici izvijestili da su drugi učenici zlostavljani } \\
\text { (iako možda nisu koristili izraz nasilje)? }\end{array}$ & 12,88 & 12 & 0,3778 \\
\hline $\begin{array}{l}\text { Ako ste uočili nasilničko ponašanje među učenicima ili ako su Vas učenici izvijestili o njemu, koliko ste } \\
\text { često prijavili ovaj incident roditeljima u ovome polugodištu? }\end{array}$ & 11,36 & 12 & 0,4983 \\
\hline $\begin{array}{l}\text { Ako ste uočili nasilničko ponašanje među učenicima ili ako su Vas učenici izvijestili o njemu, koliko ste } \\
\text { često ovo polugodište razgovarali o incidentu s ravnateljem? }\end{array}$ & 7,6 & 12 & 0,8156 \\
\hline $\begin{array}{l}\text { Ako ste uočili nasilničko ponašanje među učenicima ili ako su Vas učenici izvijestili o njemu, koliko ste } \\
\text { često ovo polugodište razgovarali o incidentu sa školskom stručnom službom (pedagog, psiholog, } \\
\text { defektolog)? }\end{array}$ & 12,64 & 12 & 0,3957 \\
\hline $\begin{array}{l}\text { Ako ste uočili nasilničko ponašanje među učenicima ili ako su Vas učenici izvijestili o njemu, koliko ste } \\
\text { često ovo polugodište razgovarali o incidentu s drugim nastavnikom? }\end{array}$ & 10,6 & 12 & 0,5635 \\
\hline $\begin{array}{l}\text { Ako ste uočili nasilničko ponašanje među učenicima ili ako su Vas učenici izvijestili o njemu, koliko ste } \\
\text { često razgovarali ovo polugodište o incidentu s drugim djelatnikom u školi? }\end{array}$ & 19,78 & 12 & 0,0714 \\
\hline $\begin{array}{l}\text { Od početka ovoga polugodišta, koliko ste često razgovarali s pojedinim učenicima, u svojoj školi, o } \\
\text { nasilničkom ponašanju prema drugima? }\end{array}$ & 10,35 & 12 & 0,5853 \\
\hline $\begin{array}{l}\text { Od početka ovoga polugodišta koliko ste često razgovarali s roditeljima djece koja su zlostavljala } \\
\text { druge (tj. govorili o djetetovu nasilju)? }\end{array}$ & 14,43 & 12 & 0,2741 \\
\hline $\begin{array}{l}\text { Od početka ovoga polugodišta, koliko često ste razgovarali s pojedinim učenicima o nasilničkom } \\
\text { ponašanju nad njima? }\end{array}$ & 16,62 & 12 & 0,1645 \\
\hline Od početka školske godine, koliko ste često razgovarali sa svojom obitelji o nasilju? & 17,03 & 12 & 0,1485 \\
\hline Vjerujete li da Vaša škola ima jasna pravila ili politiku o nasilničkom ponašanju među učenicima? & 4,69 & 9 & 0,8605 \\
\hline Vjerujete li da su Vaša školska pravila i politika o nasilničkom ponašanju jasno priopćena roditeljima? & 9,62 & 9 & 0,3821 \\
\hline $\begin{array}{l}\text { Vjerujete li da su Vaša školska pravila i politika o nasilničkom ponašanju jasno priopćena nastavnom } \\
\text { osoblju? }\end{array}$ & 4,35 & 9 & 0,8869 \\
\hline $\begin{array}{l}\text { Je li Vam jasno što trebate učiniti kako biste odgovorili na nasilje koje ste promatrali ili ste čuli o } \\
\text { njemu u svojoj školi? }\end{array}$ & 12,38 & 9 & 0,1927 \\
\hline Koliko su Vam ugodne intervencije na nasilničko ponašanje koje promatrate u svojoj školi? & 8,12 & 9 & 0,5221 \\
\hline $\begin{array}{l}\text { Koliki je postotak učenika u Vašoj školi, za koje vjerujete da su zlostavljali druge učenike jedanput na } \\
\text { tjedan ili više, od početka ovoga polugodišta? }\end{array}$ & 5 & 9 & 0,8343 \\
\hline
\end{tabular}
tjedan ili više, od početka ovoga polugodišta? 


\section{Rasprava / Discussion}

Škola kao odgojno-obrazovna ustanova potencijalno je scena na kojoj svoju dramu odigravaju nasilnici i žrtve nasilja [7]. Škola nije samo mjesto učenja u smislu prijenosa znanja, nego i prostor učenja socijalnih i životnih vještina. Upravo zbog toga škole se otvoreno moraju suočiti s problemom nasilja. Međutim, osim što nasilje predstavlja problem u školama, ono postaje problem i u društvu. Istraživanje pokazuje da su nastavnici svjesni nasilja koje se događa u njihovim učionicama, ali nisu svjesni da upravo oni moraju preuzeti aktivnu ulogu u prevenciji nasilja, da su upravo oni odgovorni za sigurnost svojih učenika i da upravo oni trebaju poduzeti sve efikasne mjere kako bi proglasili svoju učionicu "učionicom bez nasilja." Osim toga, trebalo bi raditi na podizanju javne svijesti o vršnjačkom nasilju i posljedicama vršnjačkog nasilja različitim oblicima javnih kampanja te poslati jasnu poruku javnosti da ne toleriramo nasilje $u$ svojim školama i među svojom djecom [8].

Zaključno je važno naglasiti kako je potrebno I školu naučiti da ne negira nasilje jer zbog negiranja "dječjih svađa“ možemo propustiti reagirati na vrijeme i samim time potaknuti daljnje širenje nasilja.

Stoga u niz mjera i programa koji se provode radi sprječavanja širenja nasilja u školama moraju biti uključeni nastavnici, roditelji, stručni suradnici, lokalna i šira društvena zajed- nica. Nužna je i promjena zakonskih regulativa s posebnim naglaskom na povećanje broja stručnih suradnika u vrtićima i školama te uvođenje novih kolegija u sustav obrazovanja odgajatelja i nastavnika. Prikladnom brigom stručnjaka može se preusmjeriti ponašanje nasilnika u vrtiću i školi. On ugrožava zdravlje žrtava, ali i ostale djece koja su svjedoci nasilja [9].

\section{Literatura / References}

[1] Bilić V, Buljan Flander G, Hrpka H. Nasilje nad djecom i među djecom: nasilje među vršnjacima. Naklada Slap, Zagreb, listopad 2012

[2] Olweus D. Nasilje među djecom u školi. Zagreb: Školska knjiga, 1998.

[3] Vejmelka L. Neke determinante vršnjačkog nasilja u adolescenciji: Ljetopis socijalnog rada 19 (2); 215-240.

[4] WHO: The health behaviour in school - aged children: International report from 2005/2006 survey. Preuzeto s: www.childhealthresearch. eu, 20.08.2013

[5] Kuzman M, Pavić Šimetin I, Pejnović Franelić I. Ponašanje u vezi sa zdravljem u djece školske dobi 2009/2010. Djeca i mladi u društvenom okruženju, Zagreb, 2011.

[6] Poliklinika za zaštitu djece grada Zagreba (2003). Nasilje među djecom, www.poliklinika-djeca.hr/istraživanja/nasilje-medu-djecom-3/, 20.08.2013

[7] Vuković A, Milašin A, Buljubašić Kuzmanović V. Učestalost vršnjačkog nasilja osvećivanjem kao nasilne strategije sučeljavanja među učenicima osnovne škole: Život i škola, 22 (55):78-96.

[8] Eisner M. Prema učinkovitijoj prevenciji nasilja mladih - prikaz stanja. U: Nasilje u školama - izazov lokalnoj zajednici. Izvješće s Konferencije Vijeća Europe. Zagreb,2004

[9] Zrilić S. Sudionici u krugu školskog nasilja - nasilnik, žrtva i promatrač. Magistra ladertina 1(1)2006;49-57. 